Cœnolestes. The sparassodonts (Prothylacinidæ) are also included in this radiation, although how these terrestrial types (which, as already stated, the author thinks were probably allied to the thylacine) were developed from arboreal forms is left unexplained. Finally, in the Pliocene occurred the irruption into South America of the modern opossums of that country.

It may be added that the author classifies modern marsupials by the foot-structure rather than by the dentition, thus making the two main groups Didactyla and Syndactyla, in place of Polyprotodontia and Diprotodontia.

R. L.

\section{CONTRIBUTIONS TO THE SCIENCE OF} $M E D I C I N E .^{1}$

THE handsome volume under notice contains a number of important papers of considerable interest to the physiologist, pathologist, and physician. It commences with a description, and an account of the opening, of the Johnston Laboratories for Biochemistry, Tropical, and Experimental Medicine, the munificent gift of Mr. William Johnston-hence the addition in the title of these reports. This has a melancholy interest also, since one of those who replied to the toasts on that occasion was the late Prof. Nocard.

The first paper is by Prof. Moore on the synthesis of fats accompanying intestinal absorption, in which it is shown that absorbed fat is re-synthesised to neutral fat in the intestinal mucous membrane. Neurology is represented by papers on the physiology of the cerebral cortex in anthropoid apes, by Dr. A. S. Grünbaum and Prof. Sherrington (reprinted from the Proceedings of the Royal Society, London), and on the electric conductivity of mammalian nerve, by Dr. Woodworth. Prof. Sherrington records a number of experiments carried out for the special chloroform committee of the British Medical Association on the dosage of the mammalian heart by chloroform; these have already been referred to in the columns of NATURE. Dr. Hume publishes a method for the isolation of the typhoid bacillus, based upon the greater motility of this organism compared with that of the colon bacillus, with which it is generally associated, so that the former will reach the surface of a column of viscid medium sooner than the latter when the two are introduced at the bottom. Mr. Roaf contributes a note on the influences of fiour and allied substances upon the typhoid bacillus, from which it would seem that emulsions of flour are inhibitory to the growth of this microbe. Dr. J. W. Stephens describes a modification of the Van Ermengem method for flagella staining.

The study of cancer is represented by two important papers, one by Dr. Prowse on the relation of vesicular mole to chorion carcinoma, the other by Mr. Keith Monsarrat on an organism associated with mammary carcinoma. In the last-named it is claimed that by the use of a special culture medium, round encapsuled organisms have been cultivated, the cultures in certain instances producing nodules of growth when inoculated into guinea-pigs.

The vitality of the Liverpool School of Tropical Medicine is evidenced by several contributions. Prof. Ronald Ross describes his "thick film" process for the detection of malaria and other parasites in blood. Dr. Christy and Dr. Stephens contribute papers on "tick fever" and on "blackwater fever" respectively, and Drs. Stephens and Christophers give a summary of researches on native malaria and blackwater fever, and suggestions for the prevention of these dread scourges.

Finally, the volume concludes with the report of the malaria expedition to the Gambia in 1902, by Mr. Dutton, to which an appendix is contributed by $\mathrm{Mr}$. Theobald on the mosquitoes collected in that expedition, with a description of some new species. Every paper contains the results of original work or observations of value, and the general "get up" of the volume is all that could be desired, the illustrations being numerous and excellent.

R. T. HeweETr.

1 "The Thompson-Yates and Johnst on Laboratories Reports." Vol. $v$ (New Series.) Part I. (London: Longmans, Green and Co., 1903.) NO. I 786 , vOL. 69]
UNIVERSITY AND EDUCATIONAL INTELLIGENCE.

Cambridge. - It is proposed to " affiliate" the University of King's College, Nova Scotia. Graduates in arts of that university will be admitted to the privileges of alfiliated students, namely, exemption from the previous examination and permission to proceed to the B.A. degree after six terms' residence in Cambridge.

An annual prize in civil engineering, of the value of about I $5 l$. has been founded by Mrs. Wimbolt, in memory of her late husband, Mr. J. S. Wimbolt, M.A., of Trinity College. The prize is open to Bachelors of Arts, and will be given for the best exercise or dissertation embodying the results of independent research in some subject related to the profession of a civil engineer.

THE Finance Committee of the Liverpool Corporation has decided to recommend the city council to grant to the Liverpool University 10,00ol. during the year 1904, such sum to be paid out of the city rate.

At the Northampton Institute, Clerkenwell, on Friday, February 26, Lord Kelvin will present the certificates and prizes on the occasion of the annual prize distribution and conversazione of members and students.

A CONFERENCE on nature-study, arranged by the School Nature Study Union, will be held on Saturday, January 30 , at the Passmore Edwards' Settlement, Tavistock Place, W.C. The chair will be taken by Mr. Cyril Jackson, Chief Inspector, Board of Education, and two short papers will be read by representatives of elementary and secondary schools.

\section{SOCIETIES AND ACADEMIES. LONDON.}

Royal Society, December 10, I903.- "On the Resemblances Exhibited between the Cells of Malignant Growths in Man and those of Normal Reproductive Tissues." By J. Bretland Farmer, J. E. S. Moore, and C. E. Walker.

The object of the communication is to direct attention to certain important cytological transformations exhibited during the development of malignant growths in man. The changes described appear to be diagnostic of malignant as opposed to benign growths, inasmuch as they seem to be absent from the latter class of tumours. Briefly, the authors have identified, within the proliferating edges of advancing growths, cells that exhibit a type of karyokinesis presenting an extraordinary similarity to, if not identity with, the heterotype mitosis that forms so constant a character during the production of sexual cells. This mitosis, or nuclear division, is remarkably different in character from the other divisions in the body-cells, and is recognised with ease and certainty. The nuclear chromasomes pass through a totally different series of changes as compared with those exhibited by the chromosomes of ordinary nuclei. Not only in shape is this difference manifested, but also in the reduction of their number to onehalf; and in all the subsequent cell generations that follow from a cell that has once passed through the heterotype mitosis the reduced number of chromosomes is retained in normal cases that lead to the direct formation of the sexual cells themselves. In any cells, otherwise of similar (heterotype) origin, that are not about to form actual sexual cells, variations and abnormalities may supervene.

All the principal varieties that are commonly met with during the evolution of the sexual cells have been identified in malignant growths of carcinomatous and sarcomatous types. The authors consider themselves justified in relating the malignancy of the growth with these facts, and they regard the malignant tissue in question as having originated in cells that have lost their somatic character, and have directly assumed the, nature of reproductive tissues.

They propose the term gametogenic to signify tissues that are potentially or actually about to give rise to sexual cells (gametes), whilst they call the cells that have passed through the metamorphoses indicated above, but which do not finally form functional gametes, gametoid. This expression is thus intended to embody their conclusion that the 